Contents lists available at \ournal IICET

JPPI (Jurnal Penelitian Pendidikan Indonesia)

ISSN: 2502-8103 (Print) ISSN: 2477-8524 (Electronic)

\title{
Kebutuhan layanan pendidikan khusus di sekolah dasar
}

\author{
Bahrudin Bahrudin ${ }^{\left.{ }^{*}\right)}$, Indra Jaya ${ }^{1}$, Cecep Kustandi ${ }^{1}$ \\ ${ }^{1}$ Universitas Negeri Jakarta, Indonesia
}

\begin{tabular}{l}
\hline Article Info \\
\hline Article history: \\
Received Mar $20^{\text {th }}, 2021$ \\
Revised Apr $05^{\text {th }}, 2021$ \\
Accepted May $05^{\text {th }}, 2021$ \\
\hline
\end{tabular}

\section{Keyword:}

Special needs

Special education

Elementary schools

\begin{abstract}
There is no real data on students who need special service education in elementary schools for the DKI Jakarta area. This study is interested in identifying and analyzing elementary school students who need special service education. This study will determine the real condition of the prevalence of the number of students in elementary schools who need special education services. The research method used is a quantitative approach. The instrument in this study used questions derived from the variable characteristics and characteristics of children with special needs. We collaborated with 14 elementary schools in the Thousand Islands, DKI Jakarta and the number of respondents in this study was 70 teachers. The data analysis technique was carried out by statistical analysis for quantitative. Therefore, the results obtained from a number of questions were asked to respondents and then transferred to the frequency distribution table. The results showed that the special needs most needed by students with special needs are slow learning, learning difficulties and intellectual disorders. The demand for educational services can increase family outreach efforts with schools through communication according to the types of needs of students. Inclusive school environments are ready to change and adapt and consider the needs of all people. The future research is required for an IQ test to ascertain special needs for intellectual disabilities and learning disabilities.
\end{abstract}

(C) 2021 The Authors. Published by IICET.

This is an open access article under the CC BY-NC-SA license

(https://creativecommons.org/licenses/by-nc-sa/4.0)

\section{Corresponding Author:}

Bahrudin Bahrudin,

Universitas Negeri Jakarta

Email: bahrudin@unj.ac.id

\section{Pendahuluan}

Berdasarkan hasil penelitian Bishara (2020) menunjukkan bahwa pendidikan khusus berkaitan erat dengan pendidikan bagi peserta didik yang memiliki tingkat kesulitan dalam mengikuti proses pembelajaran. Hal ini dikarenakan adanya kelainan fisik, emosional, mental, sosial dan memiliki potensi kecerdasan serta bakat istimewa (Herawati, 2016). Di Jerman, praktik pendidikan layanan khusus menggunakan istilah evidence-based practice (EbP). Istilah tersebut digunakan sehubungan dengan status pendidikan khusus, konsep dan pendekatannya (Blumenthal, Hartke, \& Voß, 2019). Hasil penelitian Kim, Zhang dan Sun (2018) menunjukkan bahwa pada tahun 1965, Amerika Serikat memiliki undang-undang pertama terkait dengan pendidikan khusus yaitu Undang-Undang Pendidikan Dasar dan Menengah (ESEA). Satu dekade kemudian, Korea memiliki undang-undang pertama yang terkait dengan pendidikan khusus yaitu Undang-Undang Promosi Pendidikan Khusus (SEPA) di tahun 1977. Tujuh belas tahun setelah ESEA dan lima tahun setelah SEPA, tepatnya di tahun 1982 Cina memperkenalkan undang-undang pertamanya yang berkaitan dengan pendidikan khusus pada Pasal 45 Konstitusi Republik Rakyat Cina (Deng \& Zhu, 2016). Meskipun undang- 
undang di Korea dan Cina mulai lebih lambat dari Amerika Serikat, legislator di kedua negara ini telah bekerja keras untuk meningkatkan kualitas hidup penyandang disabilitas (Kim, 2012).

Menurut Abu-Hamour dan Al-Hmouz (2014) pendidikan khusus di Yordania memberikan kesempatan kepada peserta didik berkubutuhan khusus untuk mengikuti pembelajaran di ruang kelas pendidikan umum. Di Korea, tanggung jawab pendidikan bagi peserta didik berkebutuhan khusus telah dianggap sebagai tanggung jawab guru pendidikan khusus (Kim, 2012). Oleh karena itu, sebagian besar guru pendidikan umum jarang atau tidak pernah mengikuti kursus pendidikan khusus selama pelatihan guru mereka. Namun, barubaru ini, baik guru pendidikan umum maupun khusus telah menyadari bahwa keduanya memainkan peran kunci dalam keberhasilan pelaksanaan pendidikan inklusif (Ostendorf \& Choi, 2017). Kurang dari 20\% guru kelas umum di sekolah inklusi telah menerima pelatihan dalam jabatan atau prajabatan dalam pendidikan khusus (Choi, Shin, \& Cho, 2017). Sedangkan di Indonesia pendidikan bagi anak berkebutuhan khusus disediakan dalam tiga macam lembaga pendidikan, yaitu Sekolah Luar Biasa (SLB), Sekolah Dasar Luar Biasa (SDLB) dan Pendidikan Terpadu (Nugroho \& Marantika, 2019). Namun, seringkali lokasi untuk SLB berada di wilayah kota provinsi maupun kota kabupaten. Sehingga, belum adanya pemerataan pendidikan kebutuhan khusus untuk anak berkebutuhan khusus (Rahim, 2016). Oleh karena itu, dibutuhkan pemerataan yang sejalan dengan karakteristik dari anak berkebutuhan khusus.

Hasil penelitian Amalia (2019) menunjukkan bahwa anak berkebutuhan khusus memiliki karakteristik salah satunya adalah down syndrom. Menurut Purwandari, Chamidah, dan Mumpuniarti (2018) kurangnya fasilitas pembelajaran untuk anak berkebutuhan dan akses masuk pendidikan khusus yang sulit membuat orang tua di pedesaan lebih memilih memasukkan anaknya di SD reguler. Chitiyo, et al. (2017) menunjukkan bahwa pendidikan khusus belum mendapat prioritas yang sama dengan seluruh sistem pendidikan. Oleh sebab itu untuk menghadapi problematika terkait hal tersebut beberapa pakar Pendidikan Khusus mulai memperkenalkan sistem baru yaitu Pendidikan Inklusif (Kim, 2012; Moberg et al., 2019; Irmawati, 2014). Menurut Efendi (2018) Penyelenggaraan pendidikan inklusi di Indonesia memberikan peluang bagi anak berkebutuhan khusus untuk dapat mengenyam pendidikan di sekolah umum. Peraturan pemerintah Indonesia secara tegas menyatakan bahwa sekolah tidak dapat menolak peserta didik inklusi karena kecacatan yang dimiliki oleh peserta didik tersebut. Menurut penelitian Chiner dan Cardona (2013) memasukkan ketentuan inklusi dan kesetaraan yang dianjurkan dalam deklarasi internasional seperti pernyataan salamanca dan kerangka aksi pendidikan kebutuhan khusus melalui pendidikan harus inklusif. Pada prinsipnya, sistem ini menuntut agar semua anak berkebutuhan khusus terlepas dari tingkat dan jenis kebutuhannya harus di didik di kelas secara penuh, disekolah terdekat bersama dengan teman sebayanya yang normal (Ediyanto, Atika, Kawai, \& Prabowo, 2017).

Mengubah paradigma pendidikan yang segregatif-ekslusif menjadi pendidikan yang inklusif bukan pekerjaan mudah. Menurut Wijaya (2019)pendidikan segregatif-eksklusif ini gagal meningkatkan pencapaian kompetensi dari akademik maupun kompetensi sosial. Dengan kata lain pendidikan inklusif seringkali dipandang sebelah mata. Sehingga, peserta didik yang berkebutuhan khusus maupun normal, tidak lagi mampu mengembangkan kepekaan sosial. Peristiwa realitas ini dapat diatasi dengan penyelenggaraan pendidikan inklusif. Berdasarkan hasil penelitian Sheehy, dan Budiyanto (2014) bagian penting dari gerakan pendidikan inklusif adalah konsensus. Semua anak, termasuk mereka yang memiliki kebutuhan khusus, harus memiliki kesempatan untuk mendapatkan pendidikan dan, pendidikan dengan teman sebayanya. Konsep dan tantangan pendidikan inklusif bergema di Indonesia yang semboyan nasionalnya adalah Bhinneka Tunggal Ika (Berbeda-beda Tetap Satu Jua) (Candra Pratiwi, 2015).

Mangunsong (2009) menjelaskan bahwa yang tergolong Anak Berkebutuhan Khusus (ABK) adalah mereka yang secara signifikan berbeda dalam beberapa dimensi yang penting dari fungsi kemanusiaan. Berdasarkan Undang-Undang Sistem Pendidikan Nasional No. 20 Tahun 2003 Pasal 32 menjelaskan bahwa pendidikan luar biasa atau pendidikan khusus merupakan pendidikan bagi peserta didik yang memiliki tingkat kesulitan dalam mengikuti proses pembelajaran karena kelainan fisik, emosional, mental, sosial dan memiliki potensi kecerdasan serta bakat istimewa. Di DKI Jakarta sejak tahun 2016 telah mencanangkan bahwa setiap sekolah umum tidak boleh menolak anak berkebutuhan khusus (Fuadi, 2015). Namun, dalam rangka penyelenggaraan pendidikan inklusif diperlukan adanya data yang jelas mengenai keberadaan anak yang membutuhkan pendidikan khusus di sekolah umum maupun sekolah inklusif (Alimin, 2013). Hal ini dikarenakan masih banyak perbedaan definisi atau batasan mengenai kebutuhan khusus tersebut (Kristiyanti, 2019). Oleh sebab itu, diperlukan pembatasan definisi mengenai peserta didik kebutuhan khusus. Menurut Kustawan (2015) ABK merupakan anak yang berkebutuhan khusus permanen dan temporer dan membutuhkan pelayanan pendidikan khusus. Sehingga potensi yang dimiliki mereka dapat berkembang secara maksimal. 
Pada penelitian ini, peserta didik yang membutuhkan pendidikan khusus dibatasi yaitu mereka yang mengalami gangguan penglihatan, pendengaran, gangguan intelektual, gangguan fisik dan motorik, gangguan emosi dan tingkah laku, kesulitan belajar, lambat belajar, autistik, ADHD dan/atau memiliki memiliki potensi kecerdasan dan bakat istimewa. Dari beberapa penelitian sebelumnya, pembahasan terkait layanan pendidikan khusus hanya berkaitan dengan analisis dan implementasi di sekolah dasar serta Perguruan Tinggi. Oleh sebab itu, peneliti tertarik melakukan penelitian mengenai peserta didik sekolah dasar yang membutuhkan pendidikan khusus di Kabupaten Kepulaun Seribu DKI Jakarta. Kebutuhan akan layanan pendidikan khusus penting untuk di telaah agar mendapatkan data yang riil mengenai prevalensi peserta didik sekolah dasar di Kepualaun Seribu yang membutuhkan layanan pendidikan khusus. Hal ini sebagai landasan penyelenggaraan pendidikan inklusif.

\section{Metode}

Dalam proses menganalisis kebutuhan layanan pendidikan khusus di sekolah dasar, metode penelitian yang digunakan adalah pendekatan kuantitatif (Zakariah, Afriani, \& Zakariah, 2020). Hal ini dikarenakan untuk mengungkapkan kebutuhan peserta didik sekolah dasar yang berkebutuhan khusus. Penelitian ini bekerja sama dengan 14 Sekolah Dasar di wilayah Kabupaten Kepulauan Seribu yang terdiri dari dua kecamatan yaitu Kecamatan Kepulauan Seribu Utara, dan Kepulauan Seribu Selatan.

Tabel 1. Instrumen Penelitian

\begin{tabular}{|c|c|c|}
\hline No. & Jenis Kebutuhan Khusus & Aspek \\
\hline 1. & Gangguan Penglihatan & $\begin{array}{ll}\text { - } & \text { Buta } \\
\text { - } & \text { Buta Fungsional } \\
\text { Low Vision }\end{array}$ \\
\hline 2. & Gangguan Pendengaran & $\begin{array}{ll}\text { - } & \text { Tunarungu ringan }(15-30 \mathrm{db}) \\
\text { - } & \text { Tunarungu sedang }(32-60 \mathrm{db}) \\
\text { - } & \text { Tunarungu berat }(61-90 \mathrm{db}) \\
\text { - } & \text { Tunarungu sangat berat }(91-120 \mathrm{db})\end{array}$ \\
\hline 3. & Gangguan Intelektual & $\begin{array}{ll}\text { - } & \text { Mampu dididik } \\
\text { - } & \text { Mampu dilatih } \\
\text { - } & \text { Mampu rawat }\end{array}$ \\
\hline 4. & Gangguan Fisik dan Motorik & $\begin{array}{ll}\text { - } & \text { Kaku Kaki } \\
\text { - } & \text { Kaku tangan } \\
\text { - } & \text { Jari lebih banyak } \\
\text { - } & \text { Jari berselaput } \\
\text { - } & \text { Gangguan tulang lebar } \\
\text { - } & \text { Abnormalitas sumsum tulang belakang }\end{array}$ \\
\hline 5. & Gangguan Emosi dan Tingkah Laku & $\begin{array}{ll}\text { - } & \text { Perilaku } \\
\text { - } & \text { Sosial } \\
\text { - } & \text { Emosional }\end{array}$ \\
\hline 6. & Kesulitan Belajar & $\begin{array}{l}\text { - } \quad \text { Keterlambatan berpikir } \\
\text { - } \quad \text { Keterlambatan merespon rangsangan dan } \\
\text { adaptasi }\end{array}$ \\
\hline 7. & Lambat Belajar & $\begin{array}{ll}\text { - } & \text { Tidak mampu melaksanakan tugas } \\
\text { sekolah } \\
\text { - } \quad \text { Memiliki potensi intelektual dibawah } \\
\text { normal }\end{array}$ \\
\hline & Autis & $\begin{array}{l}\text { - } \text { Kelemahan dalam interaksi sosial } \\
\text { - } \text { Kelemahan dalam komunikasi } \\
\text { - } \quad \text { Memiliki perilaku yang kurang wajar }\end{array}$ \\
\hline 9. & Cerdas Istimewa dan Bakat Istimewa & $\begin{array}{l}\text { - } \text { Memiliki rasa Keingintahuan yang tinggi } \\
\text { - } \quad \text { Menyukai tantangan } \\
\text { - } \quad \text { Tidak mudah puas dan ulet dalam berusha }\end{array}$ \\
\hline
\end{tabular}

Sumber: (Wulan, 2011; Marlina, 2015; Irvan, 2020) 
Pengumpulan data dilakukan melalui metode survey dengan menyebarkan angket yang berdasarkan panduan penangan anak berkebutuhan khusus bagi pendamping oleh Kementerian Pemberdayaan Perempuan dan Perlindungan Anak terkait teori jenis anak berkebutuhan khusus (KPPPA, 2013). Variabel yang diteliti adalah kebutuhan layanan pendidikan khusus di sekolah dasar. Populasi dalam penelitian ini adalah 14 Sekolah Dasar Negeri dan Swasta di wilayah Kepulauan Seribu dengan jumlah populasi 2.539 guru. Oleh sebab itu, peneliti menentukan sampel melalui teknik multistage random sampling. Sehingga penentuan sampel dikelompokkan menurut kelasnya, dan pengalamannya mengajar ABK. Kemudian, masing-masing kelompok diambil sampelnya secara acak untuk mewakiliki daerahnya yaitu Kecamatan Kepulauan Seribu Utara dan Selatan. Sehingga peneliti mengambil sampel guru yang menangani anak terindikasi berkebutuhan khusus di Sekolah Dasar Kecamatan Kepulauan Seribu Utara dan Selatan dengan jumlah responden 40 (laki-laki) dan 30 (perempuan). Instrumen dalam penelitian ini menggunakan pertanyaan-pertanyan yang diturunkan dari variable karakteristik dan ciri-ciri anak berkebutuhan khusus yang dikembangkan oleh Irvan (2020) dan Amelia (Amelia, 2016) (lihat Tabel 1).

Instrumen pada tabel 1 kemudian dikembangkan dalam angket melalui skala Guttman. Perhitungan skala Guttman menggunakan skoring perhitungan ya $=1$ dan tidak $=0$. Kemudian, skor tersebut dikonversikan dalam presentase. Sehingga, secara logika skor tersebut dijabarkan untuk kategori ya $1=1 \times 100 \%$. Sedangkan kategori tidak $0=0 \times 100 \%=0 \%$. Teknik analisis data dilakukan dengan analisis statistika untuk kuantitatif. Oleh karena itu, hasil yang diperoleh dari sejumlah pertanyaan diajukan kepada responden lalu dipindahkan ke tabel distribusi frekuensi. Sehingga, hasil tersebut dapat memperlihatkan jumlah dari anak yang membutuhkan layanan pendidikan khusus.

\section{Hasil dan Pembahasan}

Dalam pendidikan inklusif setiap peserta didik dipandang memiliki karakter dan kebutuhan khusus masingmasing yang berbeda-beda sesuai dengan kondisi individu peserta didik, baik itu kebutuhan yang bersifat permanen ataupun yang bersifat sementara. Oleh sebab itu, melakukan identifikasi terkait layanan pendidikan khusus penting dalam meningkatkan kualitas belajar yang setara. Berdasarkan hasil temuan, kami memberikan angket kepada 35 guru di Sekolah Dasar wilayah Kecamatan Kepulauan Seribu Utara terdiri dari 7 (tujuh) sekolah dasar dengan seluruh peserta didik berjumlah 1.459. Berikut ini karaktersitk dari responden:

Tabel 2. Karakteristik Responden Guru di Kecamatan Kepulauan Seribu Utara

\begin{tabular}{llcc}
\hline No. & \multicolumn{1}{c}{ Demografi Responden } & Jumlah & Presentase \\
\hline 1 & Usia (tahun) & 20 & $57 \%$ \\
& $25-45$ & 15 & $43 \%$ \\
\hline $26-56$ & Jenis Kelamin & & \\
& Perempuan & 18 & $51.4 \%$ \\
& Laki-laki & 17 & $48.6 \%$ \\
\hline 3 & Lama Mengajar (tahun) & & \\
& $5-15$ & 22 & $63 \%$ \\
& $>15$ & 13 & $37 \%$ \\
\hline
\end{tabular}

Tabel 2 menunjukkan bahwa responden dengan lama mengajar 5 sampai 15 tahun berjumlah $63 \%$ atau sekitar 22 tahun. Hal ini menunjukkan bahwa guru yang ada di Kecamatan Kepulauan Seribu Utara memiliki pengalaman panjang dalam mengajar. Oleh sebab itu, guru memiliki kemampuan untuk menganalisis karakteristik peserta didik. Disamping itu, berdasarkan aspek usia guru menunjukkan bahwa seluruh respon berada pada usia yang produktif. Sehingga diharapkan guru mampu untuk melakukan adaptasi terhadap ABK. Kemudian, guru dari 7 (tujuh) sekolah yang terletak di Kecamatan Kepulauan Seribu Utara kami arahkan untuk melakukan identifikasi peserta didik yang mengalami kebutuhan khusus dimasing-masing sekolah. Berdasarkan hasil penelitian, maka data mengenai jumlah anak berkebutuhan khusus di Kecamatan Kepulauan Seribu Utara, sebagai berikut: 
Tabel 3 Jumlah anak membutuhkan layanan pendidikan khusus di kecamatan Kepulauan Seribu Utara

\begin{tabular}{|c|c|c|c|c|c|}
\hline No. & Jenis Kebutuhan Khusus & Jumlah Guru & $\begin{array}{c}\text { Presentase } \\
(\%)\end{array}$ & Jumlah ABK & Presentase (\%) \\
\hline 1. & Gangguan Penglihatan & 0 & 0 & 0 & 0 \\
\hline 2. & Gangguan Pendengaran & 2 & 5.7 & 2 & 3.9 \\
\hline 3. & Gangguan Intelektual & 10 & 28.6 & 10 & 19.2 \\
\hline 4. & $\begin{array}{l}\text { Gangguan Fisik dan } \\
\text { Motorik }\end{array}$ & 1 & 2.9 & 1 & 1.8 \\
\hline 5. & $\begin{array}{l}\text { Gangguan Emosi dan } \\
\text { Tingkah Laku }\end{array}$ & 0 & 0 & 0 & 0 \\
\hline 6. & Kesulitan Belajar & 8 & 22.9 & 10 & 19.2 \\
\hline 7. & Lambat Belajar & 12 & 34.2 & 27 & 52 \\
\hline 8. & Autis & 2 & 5.7 & 2 & 3.9 \\
\hline \multirow[t]{2}{*}{9.} & $\begin{array}{l}\text { Cerdas Istimewa dan Bakat } \\
\text { Istimewa }\end{array}$ & 0 & 0 & 0 & 0 \\
\hline & Jumlah & 35 & $100 \%$ & 52 & $100 \%$ \\
\hline
\end{tabular}

Berdasarkan hasil angket yang diberikan oleh peneliti menunjukkan bahwa 12 guru dari 7 Sekolah Dasar wilayah Kecamatan Kepulauan Seribu Utara terdapat peserta didik berkebutuhan khusus yang memiliki jenis lambat belajar. Dari data tabel 3, 12 guru tersebut teridentifikasi 27 peserta didik (52\%) yang memiliki kebutuhan pendidikan khusus jenis lambat belajar. Selain jenis tersebut, peserta didik juga terindikasi gangguan intelektual (19.2\%) dan kesulitan belajar (19.2\%) di Sekolah Dasar. Hal ini sejalan dengan Gearheart dalam Rahmawati, Firmiana, dan Imawati (2017) bahwa peserta didik dianggap memiliki kebutuhan khusus apabila memerlukan persyaratan pendidikan yang berbeda dari rata-rata mereka yang normal. Hal ini dikarenakan kekhususan yang relevan dari perbedaan cara belajar yang membutuhkan instruksi berbeda dari pada peserta didik pada umumnya (Amelia,2016). Kekhususan mereka dapat mencakup bidang sensori, fisik, kognitif, emosi, atau kemampuan komunikasi atau kombinasi. Kekhususan bisa sangat berbeda dalam penyebab, tingkat keparahan, dampak bagi kemajuan pendidikan, dan dampak yang berbeda ini pun bisa tergantung dari usia seseorang, jenis kelamin, dan lingkungan hidupnya (Lee et al., 2015). Oleh sebab itu, tidak mengherankan bila munculnya inklusi memberikan manfaat kepada peserta didik berkebutuhan khusus di kelas inklusif lebih mampu belajar, membuat lebih banyak kemajuan dalam keterampilan akademik, dan mengembangkan perilaku adaptif bila dibandingkan dengan peserta didik yang dididik di sekolah luar biasa (Dessemontet, Bless, \& Morin, 2012). Sehingga, data tabel 3 menunjukkan bahwa di Kepulauan Seribu masih terdapat Sekolah Dasar yang membutuhkan layanan pendidikan khusus untuk peserta didik berkebutuhan khusus. Di Kecamatan Kepulauan Seribu Selatan, peneliti menemukan hasil penelitian melalui hasil angket yang diberikan kepada 35 guru yang terdiri dari 7 (tujuh) sekolah dasar dengan seluruh peserta didik berjumlah 1.080. Berikut ini karakteristik responden:

Tabel 4. Karakteristik Responden Guru di Kecamatan Kepulauan Seribu Selatan

\begin{tabular}{llcc}
\hline No. & \multicolumn{1}{c}{ Demografi Responden } & Jumlah & Presentase \\
\hline $\mathbf{1}$ & Usia (tahun) & & \\
& $25-45$ & 28 & $80 \%$ \\
& $46-56$ & 7 & $20 \%$ \\
\hline $\mathbf{2}$ & Jenis Kelamin & & \\
& Perempuan & 19 & $54 \%$ \\
& Laki-laki & 16 & $46 \%$ \\
\hline $\mathbf{3}$ & Lama Mengajar (tahun) & & \\
& $5-15$ & 16 & $46 \%$ \\
& $>15$ & 19 & $54 \%$ \\
\hline
\end{tabular}

Tabel 4 menunjukkan bahwa karakteristik responden di Kecamatan Kepulauan Seribu Selatan dengan Utara memiliki perbandingan signifikan pada lama mengajar. Dari 35 responden, 54\% atau 19 guru memiliki pengalaman mengajar lebih dari 15 tahun. Hal ini dapat membantu peneliti dalam melakukan identifikasi terhadap peserta didik yang mengalami kebutuhan khusus. Berdasarkan pendapat Skjorten dalam Suparno 
(2010) peserta didik berkebutuhan khusus dimaknai sebagai seseorang yang memiliki hambatan dan perkembangan temporer, permainan, atau disabiliri (kecacatan) yang tidak hanya disebabkan oleh kelainan. Kondisi tersebut dapat pula disebabkan oleh kondisi sosial, emosional, atau kultural. Sehingga, dari hasil identifikasi melalui angket yang disebarkan kepada guru menunjukkan bahwa terdapat kebutuhan layanan pendidikan khusus kepada peserta didik berkebutuhan khusus di Sekolah Dasar (tabel 5):

Tabel 5. Jumlah anak membutuhkan layanan pendidikan khusus di kecamatan Kepulauan Seribu Selatan

\begin{tabular}{|c|c|c|c|c|c|}
\hline No. & Jenis Kebutuhan Khusus & Jumlah Guru & Presentase (\%) & Jumlah ABK & Presentase (\%) \\
\hline 1. & Gangguan Penglihatan & 1 & 2.9 & 1 & 2.5 \\
\hline 2. & Gangguan Pendengaran & 1 & 2.9 & 1 & 2.5 \\
\hline 3. & Gangguan Intelektual & 5 & 14.3 & 10 & 25 \\
\hline 4. & $\begin{array}{l}\text { Gangguan Fisik dan } \\
\text { Motorik }\end{array}$ & 3 & 8.5 & 3 & 7.5 \\
\hline 5. & $\begin{array}{l}\text { Gangguan Emosi dan } \\
\text { Tingkah Laku }\end{array}$ & 2 & 5.7 & 2 & 5 \\
\hline 6. & Kesulitan Belajar & 10 & 28.6 & 10 & 25 \\
\hline 7. & Lambat Belajar & 12 & 34.2 & 12 & 30 \\
\hline 8. & Autis & 0 & 0 & 0 & 0 \\
\hline 9. & $\begin{array}{l}\text { Cerdas Istimewa dan Bakat } \\
\text { Istimewa }\end{array}$ & 0 & 0 & 0 & 0 \\
\hline \multirow[t]{2}{*}{10.} & ADHD & 1 & 2.9 & 1 & 2.5 \\
\hline & Jumlah & 35 & $100 \%$ & 40 & $100 \%$ \\
\hline
\end{tabular}

Data tabel 5 menunjukkan bahwa kebutuhan layanan pendidikan khusus bagi peserta didik berkebutuhan khusus di Sekolah Dasar paling tinggi adalah jenis kebutuhan khusus lambat belajar. Hal ini sesuai dengan hasil temuan peneliti dari 35 responden 12 (34.2\%) diantaranya memiliki peserta didik berkebutuhan khusus dengan jenis lambat belajar sebesar 30\%. Berdasarkan hasil penelitian Fabela-Cardenas dan Robles-Trevino (2012) pendidikan inklusif telah meningkatkan kualitas, kegunaan dan kemandirian bagi peserta didik. Tugas ini tidak semudah kelihatannya. Untuk memenuhi kebutuhan peserta didik, diperlukan dukungan dari orangorang yang tertarik pada kesejahteraan mereka, seperti pembuat kebijakan, administrator sekolah, guru, spesialis, dokter, psikolog, dan orang tua(Rahmawati et al., 2017). Oleh sebab itu, agar dapat terakomodir dengan baik kebutuhan peserta didik berkebutuhan khusus, identifikasi ini dibutuhkan agar dapat melihat jenis kebutuhan yang diperlukan untuk dikembangkan(Alimin, 2013). Sehingga tabel 5 memberikan gambaran bahwa selain jenis lambat belajar, layanan pendidikan khusus lainnya yang dibutuhkan adalah jenis kesulitan belajar dan gangguan intelektual masing-masing 25\%.

Diantara kedua Kecamatan Kepulauan Seribu Utara dan Selatan menunjukkan bahwa kedua daerah tersebut sangat membutuhkan layanan pendidikan khusus. Hal ini berdasarkan tabel 3 dan tabel 5 yang menggambarkan peserta didik di kedua daerah tersebut sama-sama membutuhkan layanan dengan jenis kebutuhan khusus lambat belajar, kesulitan belajar, dan gangguan intelektual. Hanya saja, tidak menutup kemungkinan baik tabel 3 dan tabel 5 menunjukkan jenis kebutuhan lainnya seperti gangguan pendengaran, gangguan fisik dan motorik, autis, gangguan penglihatan, gangguan emosi dan tingkah laku serta ADHD. Walaupun memang persentasenya tidak banyak. Disamping itu berdasarkan jumlah peserta didik di 7 (tujuh) Sekolah Dasar sebesar 1459 wilayah Kecamatan Kepulauan Seribu Utara hanya 52 (3.5\%) peserta didik yang terindikasi berkebutuhan khusus. Sedangkan di wilayah Kecamatan Kepulauan Seribu Selatan dari 1080 peserta didik di 7 (tujuh) Sekolah Dasar 40 (3.7\%) peserta didik yang memiliki kebutuhan khusus. Sehingga, Kecamatan Kepulauan Seribu Utara menjadi daerah pertama yang harus ditinjau untuk diberikan layanan pendidikan khusus. Hal ini di dasari oleh jumlah ABK yang lebih tinggi dibandingkan dengan Kecamatan Kepulauan Seribu Selatan. Meskipun begitu, sekolah dasar di wilayah Kecamatan Kepulauan Seribu Selatan juga harus mendapatkan perhatian karena terdapat 40 peserta didik ABK. Hal ini dikarenakan semua peserta didik membutuhkan dukungan untuk berkembang dan mendapatkan manfaat penuh dari pengalaman sekolah mereka(Irmawati, 2014). Peserta didik berkebutuhan khusus yang memiliki pembelajaran, perilaku, komunikasi, intelektual dan fisik atau beberapa pengecualian memiliki kebutuhan pendidikan yang tidak dapat dipenuhi melalui pembelajaran reguler dan praktik penilaian(Irvan, 2020). Sehingga, kebutuhan bagi peserta didik yang memiliki karakteristik ABK dapat dipenuhi melalui layanan pendidikan khusus(Abu-Hamour \& Al-Hmouz, 2014).

Berdasarkan UUD 1945 pasal 28C ayat (1) menjelaskan bahwa setiap orang berhak untuk mengembangkan diri melalui pemenuhan kebutuhan dasarnya, berhak mendapat pendidikan dan memperoleh manfaat dari ilmu pengetahuan dan teknologi, seni dan budaya, demi meningkatkan kualitas hidupnya dan demi kesejahteraan umat. 
Hal ini menunjukkan bahwa peserta didik ABK juga memiliki kesempatan yang sama dalam mendapatkan pendidikan. Namun, berdasarkan hasil temuan menunjukkan bahwa 14 (empat belas) skolah dasar yang berada di wilayah Kecamatan Kepulauan Seribu Utara dan Selatan masih ada yang belum mendapatkan layakanan pendidikan khusus. Kebutuhan akan layananan pendidikan khusus ini juga terjadi di Yordania. Hasil penelitian Abu-Hamour dan Al-Hmouz (2014) juga menunjukkan sebagian besar siswa berkebutuhan khusus di Yordania biasanya dikeluarkan atau putus sekolah umum karena layanan dan penilaian yang memadai tidak diberikan untuk membantu mereka berhasil. Sehingga peristiwa ini tidak seharusnya terjadi di wilayah Kepulauan Seribu. Selain di Indonesia dan Yordania, Thailand memiliki metode yang berbeda untuk menentukan apakah seorang anak memiliki kebutuhan pendidikan khusus atau tidak(Vorapanya \& Dunlap, 2012). Metode tersebut dilakukan melalui proses penilaian yang dilakukan oleh dokter sebelum anak tersebut masuk sekolah. Selanjutnya dari hasil penilaian tersebut dokter akan mengeluarkan seritifkat berkebutuhan khusus bagi anak yang digunakan untuk mendaftar ke sekolah(Vibulpatanavong, 2018).

Temuan kami dengan jelas menunjukkan masih ada peserta didik yang belum mendapatkan layanan pendidikan khusus. Hal ini juga terjadi di Afrika Selatan bahwa adanya ketegangan antara isi kebijakan, realitas sistemik termasuk kendala pendanaan menjadi latar belakang layanan pendidikan khusus masih kurang dapat maksimal diberikan kepada peserta didik ABK(Engelbrecht, Nel, Smit, \& Van Deventer, 2016). Menurut penelitian Handayani dan Rahadian (2013) kurangnya layanan pendidikan khusus kepada peserta didik ABK selain peraturan yang belum mengakomodasi konsep pendidikan inklusif juga kurangnya guru, infrastruktur, dan dukungan dari masyarakat. Melalui penelitian ini, sekolah dasar baik di Kepulauan Seribu dan seluruh Indonesia harus menyediakan pendidikan berkualitas untuk berbagai kebutuhan pembelajaran. Disamping itu, peserta didik penyandang disabilitas tidak boleh dikecualikan dari ruang kelas pendidikan umum dan harus diberikan kesempatan untuk berpartisipasi penuh dalam kegiatan sehari-hari di ruang kelas umum. Menurut Morina (2017) pendidikan inklusif berkaitan erat dengan pendekatan pendidikan yang mengusulkan sekolah di mana semua peserta didik dapat berpartisipasi dan semua diperlakukan seperti anggota sekolah yang berharga. Berdasarkan hasil temuan menunjukkan bahwa analisis kekhawatiran tentang pendidikan inklusif tampaknya menunjukkan bahwa banyak guru memiliki sikap positif terhadap inklusi tetapi masih memiliki kekhawatiran tentang adaptasi dan modifikasi pengaturan kelas (Boyle, Topping, Jindal-Snape, \& Norwich, 2012). Namun hal ini tidak bisa kita biarkan terus menerus. Oleh karena itu, mereka membutuhkan layanan yang dapat membantu peserta didik berkebutuhan khusus di tingkat sekolah dasar(Saputra, 2016). Sehingga penelitian ini dapat dijadikan sebagai dasar bagi dinas pendidikan untuk dapat memberikan pendidikan inklusif tanpa pengecualian kepada peserta didik (Chiner \& Cardona, 2013).

Penelitian ini juga menunjukkan bahwa kebutuhan layanan pendidikan ini akan dapat meningkatkan upaya penjangkauan keluarga dengan sekolah melalui komunikasi sesuai dengan jenis kebutuhan peserta didik. Berdasarkan hasil temuan penelitian, jenis kebutuhan dengan jumlah ABK tertinggi baik di Kecamatan Kepulauan Seribu Utara dan Selatan adalah lambat belajar. Slow learner memiliki rentang perhatian yang pendek serta memiliki ciri fisik normal namun sulit menangkap materi (Khabibah, 2013). Namun, peserta didik yang dikatakan slow learner memiliki IQ 80-90 (Lisnawati \& Muthmainah, 2018). Sehingga, slow learner atau lambat belajar harus mendapatkan perhatian khusus. Hasil penelitian Lisnwati dan Muthmainah (2018) menunjukkan bahwa untuk meningkatkan keterampilan membaca bagi slow learner di sekolah dasar dapat dilakukan melalui metode struktur analitik sintetik. Oleh sebab itu, lingkungan sekolah inklusif sudah seharusnya siap mengubah dan menyesuaikan serta mempertimbangkan kebutuhan semua orang(Candra Pratiwi, 2015). Guru yang mengajar ABK tidak lagi menyesuaikan diri dengan pengaturan yang ada, tetapi harus menyesuaikan dengan kebutuhan anak. Sehingga pendidikan inklusif yang dibutuhkan oleh peserta didik berkebutuhan khusus memberikan kesempatan keluarga, guru, dan masyarakat terlibat dalam pembelajaran anak(Page et al., 2021). Disamping itu, melihat kebutuhan layanan pendidikan khusus bagi sekolah dasar di Kecamatan Kepulauan Seribu Utara dan selatan haruslah melibatkan semua anak tanpa memandang perbedaan lingkungan. Meskipun jenis kebutuhan khusus lambat belajar memiliki presentase yang tinggi, namun ada pula jenis kebutuhan khusus lain yang harus diperhatikan seperti gangguan intelektual, dan kesulitan belajar. Hal ini perlu dilakukan sebagai upaya pemerintah dalam mewujudkan pendidikan yang setara bagi seluruh masyarakat di Indonesia.

\section{Simpulan}

Dari hasil penelitian tersebut dapat disimpulkan bahwa peserta didik yang mebutuhkan layanan pendidikan khusus tingkat sekolah dasar di Kecamatan Kepulauan Seribu Utara dan Selatan yaitu jenis berkebutuhan khusus lambat belajar, kesulitan belajar serta gangguan intelektual. Meskipun begitu, penelitian ini memberikan gambaran bahwa selalu ada perbedaan antara pendapat guru dan praktik yang terlibat dalam penerapan praktik inklusif. Berdasarkan kesimpulan tersebut di atas dapat disarankan untuk mengetahui estimasi anak berkebutuhan khusus dapat dilakukan dengan lebih banyak melibatkan professional yang terkait 
dengan anak berkebutuhan khusus. Oleh sebab itu penelitian yang akan datang diperlukan adanya tes IQ untuk memastikan jenis kebutuhan khusus gangguan intelektual maupun lambat belajar.

\section{Referensi}

Abu-Hamour, B., \& A1-Hmouz, H. (2014). Special education in Jordan. European Journal of Special Needs Education, 29(1), 105-115. https://doi.org/10.1080/08856257.2013.859820

Alimin, Z. (2013). Paradigma Pendidikan Inklusif sebagai Upaya Memperluas Akses dan Perbaikan Mutu Pendidikan. Jassi Anakku, 12(2), 171-180.

Amalia, R. (2019). Implementasi Pendidikan terhadap Pola Kebiasaan Anak Berkebutuhan Khusus (Studi Kasus Kehidupan Septi Anak diduga Down Syndrome di Dusun Jetis Desa Mororejo Kec. Tempel Sleman Yogyakarta). Golden Age: Jurnal Ilmiah Tumbuh Kembang Anak Usia Dini, 4(4), $19-26$. https://doi.org/10.14421/jga.2019.44-03

Amelia, W. (2016). Karakteristik dan Jenis Kesulitan Belajar Anak Slow Learner. Jurnal Aisyah : Jurnal Ilmu Kesehatan, 1(2), 53-58. https://doi.org/10.30604/jika.v1i2.21

Bishara, S. (2020). Association between Phonological and Morphological Awareness and Reading Comprehension among Special-Education Children in Arab Elementary Schools. International Journal of Disability, Development and Education, O(0), 1-18. https://doi.org/10.1080/1034912X.2020.1737319

Blumenthal, Y., Hartke, B., \& Voß, S. (2019). The role of evidence-based practice in german special education-state of research and discussion. Education Sciences, $9(2)$. https://doi.org/10.3390/educsci9020106

Boyle, C., Topping, K., Jindal-Snape, D., \& Norwich, B. (2012). The importance of peer-support for teaching staff when including children with special educational needs. School Psychology International, 33(2), 167184. https://doi.org/10.1177/0143034311415783

Candra Pratiwi, J. (2015). Sekolah Inklusi Untuk Anak Berkebutuhan Khusus: Tanggapan Terhadap Tantangan Kedepannya. Prosiding Seminar Nasional Pendidikan "Meretas Sukses Publikasi Ilmiah Bidang Pendidikan Jurnal Bereputasi," 237-242.

Chiner, E., \& Cardona, M. C. (2013). International Journal of Inclusive Inclusive education in Spain : how do skills, resources, and supports affect regular education teachers ' perceptions of inclusion? Journal of Inclusive Education, 15(5), 526-541. https://doi.org/10.1080/13603116.2012.689864

Chitiyo, M., Hughes, E. M., Changara, D. M., Chitiyo, G., \& Montgomery, K. M. (2017). Special education professional development needs in Zimbabwe. International Journal of Inclusive Education, 21(1), 48-62. https://doi.org/10.1080/13603116.2016.1184326

Choi, N., Shin, M., \& Cho, E. M. (2017). Policies and issues surrounding the identification of students with learning disabilities in South Korea. International Journal of Special Education, 32(2), 439-457.

Deng, M., \& Zhu, X. (2016). Special Education Reform Towards Inclusive Education: Blurring or Expanding Boundaries of Special and Regular Education in China. Journal of Research in Special Educational Needs, 16, 994-998. https://doi.org/10.1111/1471-3802.12244

Dessemontet, R. S., Bless, G., \& Morin, D. (2012). Effects of inclusion on the academic achievement and adaptive behaviour of children with intellectual disabilities. Journal of Intellectual Disability Research, 56(6), 579-587. https://doi.org/10.1111/j.1365-2788.2011.01497.x

Ediyanto, E., Atika, I. N., Kawai, N., \& Prabowo, E. (2017). Inclusive Education in Indonesia From the Perspective of Widyaiswara in Centre for Development and Empowerment of Teachers and Education Personnel of Kindergartens and Special Education. IJDS : Indonesian Journal of Disability Studies, 4(2), 04116. https://doi.org/10.21776/ub.ijds.2017.004.02.3

Efendi, M. (2018). The Implementation of Inclusive Education in Indonesia for Children with Special Needs: Expectation and Reality. Journal of ICSAR, 2(1), 142-147. https://doi.org/10.5195/ehe.2011.27

Engelbrecht, P., Nel, M., Smit, S., \& Van Deventer, M. (2016). The idealism of education policies and the realities in schools: The implementation of inclusive education in South Africa. International Journal of Inclusive Education, 20(5), 520-535. https://doi.org/10.1080/13603116.2015.1095250

Fabela-Cárdenas, M. A., \& Robles-Treviño, L. (2012). Teachers' Perceptions of Collaboration and Partnership regarding Children with Special Educational Needs in a Mexican Bilingual Elementary School. Global Studies of Childhood, 2(1), 70-75. https://doi.org/10.2304/gsch.2012.2.1.70

Fuadi, K. (2015). Analisis Kebijakan Penyelenggaraan Pendidikan Inklusif di Provinsi DKI Jakarta. Hikmah: Journal of Islamic Studies, 11(2).

Handayani, T., \& Rahadian, A. S. (2013). Peraturan perundangan dan implementasi pendidikan inklusif. $\begin{array}{llll}\text { Masyarakat } \quad \text { Indonesia, } & 39(1), & \text { 27-48. } & \text { Retrieved }\end{array}$ http://jmi.ipsk.lipi.go.id/index.php/jmiipsk/article/viewFile/307/178

Herawati, N. I. (2016). Pendidikan Inklusif. EduHumaniora: Jurnal Pendidikan Dasar, 2(1). 
Irmawati, R. (2014). Implementasi Kebijakan Pendidikan Inklusif Untuk Memperoleh Pendidikan Bermutu Bagi Anak Berkebutuhan Khusus (ABK) (Studi pada Sekolah Dasar Negeri Sumbersari 1 Kota Malang). Jurnal Administrasi Publik, 2(7).

Irvan, M. (2020). Urgensi Identifikasi dan Asesmen Anak Berkebutuhan Khusus Usia Dini. Jurnal Ortopedagogia, 6(2), 108-112.

Khabibah, N. (2013). Penanganan Instruksional Bagi Anak Lambat Belajar ( Slow Learner ). Didaktita, 19, 2632.

Kim, E., Zhang, J., \& Sun, X. (2018). Comparison of special education in the United States, Korea, and China. International Journal of Special Education, 33(4), 796-814.

Kim, Y. W. (2012). Inclusive education in South Korea. International Journal of Inclusive Education, 18(10), 979990. https://doi.org/10.1080/13603116.2012.693402

KPPPA. (2013). Panduan Penanganan Anak Berkebutuhan Khusus Bagi Pendamping (Orang Tua, Keluarga, dan Masyarakat).

Kristiyanti, E. (2019). Model Penyelenggaraan Pendidikan Inklusif bagi Penyandang Disabilitas Intelektual: Studi Kasus di DKI Jakarta. Indonesian Journal of Religion and Society, 1(1), 66-79.

Kustawan, D. (2015). Pendidikan Inklusif dan Upaya Implementasinya. Jakarta: PT Luxima Metro Media.

Lee, F. L. M., Yeung, A. S., Tracey, D., \& Barker, K. (2015). Inclusion of Children With Special Needs in Early Childhood Education: What Teacher Characteristics Matter. Topics in Early Childhood Special Education, 35(2), 79-88. https://doi.org/10.1177/0271121414566014

Lisnawati, L., \& Muthmainah, M. (2018). Efektivitas Metode Sas (Struktur Analitik Sintetik) Dalam Meningkatkan Keterampilan Membaca Bagi Anak Lambat Belajar (Slow Learner) Di Sdn Demangan. Jurnal Psikologi Integratif, 6(1), 81. https://doi.org/10.14421/jpsi.v6i1.1468

Mangunsong, F. (2009). Psikologi dan Pendidikan Anak Berkebutuhan Khusus. Depok: LPSP 3 UI.

Marlina. (2015). Asesmen Anak Berkebutuhan Khusus (Pendekatan Psikoedukasional). Padang: UNP Press Padang.

Moberg, S., Muta, E., Korenaga, K., Kuorelahti, M., \& Savolainen, H. (2019). Struggling for inclusive education in Japan and Finland: teachers' attitudes towards inclusive education. European Journal of Special Needs Education, O(0), 1-15. https://doi.org/10.1080/08856257.2019.1615800

Moriña, A. (2017). Inclusive education in higher education: challenges and opportunities. European Journal of Special Needs Education, 32(1), 3-17. https://doi.org/10.1080/08856257.2016.1254964

Nugroho, H., \& Marantika, N. (2019). Perencanaan Komunikasi Pendidikan Karakter Bagi Anak Berkebutuhan Khusus Sekolah Dasar Muhammadiyah Kota Madiun. Sahafa Journal of Islamic Communication, 1(2), 157. https://doi.org/10.21111/sjic.v1i2.2908

Ostendorf, R. J., \& Choi, N. (2017). Cultural and linguistic diversity in special education in the United States and South Korea: Exploring current practices and recommendations. International Journal of Special Education, 32(4), 793-808.

Page, A., Charteris, J., Anderson, J., Boyle, C., Page, A., Charteris, J., ... Boyle, C. (2021). Fostering school connectedness online for students with diverse learning needs : inclusive education in Australia during the COVID-19 pandemic ABSTRACT. European Journal of Special Needs Education, O(0), 1-15. https://doi.org/10.1080/08856257.2021.1872842

Purwandari, E., Chamidah, A. N., \& Mumpuniarti. (2018). Pemberdayaan Orang Tua Dan Masyarakat Di Desa Balingasal Dalam Identifikasi Anak Berkebutuhan Khusus. Jurnal Pendidikan Khusus, 13(2), 14-21. https://doi.org/10.21831/jpk.v13i2.19133

Rahim, A. (2016). Pendidikan Inklusif Sebagai Strategi Dalam Mewujudkan Pendidikan Untuk Semua. Jurnal Pendidikan Ke-SD-An, 3(1), 68-71.

Rahmawati, S., Firmiana, M. E., \& Imawati, R. (2017). Kesadaran dan Pengetahuan untuk Penanganan Awal Anak Berkebutuhan Khusus di Lembaga PAUD Pesanggrahan Jakarta. JURNAL Al-AZHAR INDONESIA SERI HUMANIORA, 3(2), 169. https://doi.org/10.36722/sh.v3i2.206

Saputra, A. (2016). Kebijakan pemerintah terhadap pendidikan inklusif. Golden Age Jurnal Ilmiah Tumbuh Kembang Anak Usia Dini, 1(3), 1-14. Retrieved from http://ejournal.uinsuka.ac.id/tarbiyah/index.php/goldenage/article/download/1929/1408/

Sheehy, K., \& Budiyanto. (2014). Teachers ' attitudes to signing for children with severe learning disabilities in Indonesia. International Journal of Inclusive Education, 18(11), 1143-1161. https://doi.org/10.1080/13603116.2013.879216

Suparno. (2010). Pendidikan Inklusif untuk Anak Usia Dini. Jurnal Pendidikan Khusus, 7(2).

Vibulpatanavong, K. (2018). Inclusive Education in Thailand. Advances in Social Science, Education and Humanities Research (ASSEHR), 169, 67-70. https://doi.org/10.2991/icece-17.2018.16

Vorapanya, S., \& Dunlap, D. (2012). Inclusive education in Thailand: Practices and challenges. International Journal of Inclusive Education, 18(10), 1014-1028. https://doi.org/10.1080/13603116.2012.693400

Wijaya, D. (2019). Manajemen Pendidikan Inklusif Sekolah Dasar. Jakarta: Prenada Media. 
Wulan, D. K. (2011). Peran Pemahaman Karakteristik Siswa Cerdas Istimewa Berbakat Istimewa (Cibi) dalam Merencanakan Proses Belajar yang Efektif dan Sesuai Kebutuhan Siswa. Humaniora, $2(1), 269$. https://doi.org/10.21512/humaniora.v2i1.3002

Zakariah, M. A., Afriani, V., \& Zakariah. (2020). Metodologi Penelitian Kualitatif, Kuantitatif, Action Research, Research and Development (RnD). Kolaka: Yayasan Pondok Pesantren Al Mawaddah Warrahmah Kolaka. 